\title{
Bait and the susceptibility of American lobsters Homarus americanus to epizootic shell disease
}

\author{
N. David Bethoney ${ }^{1, *}$, Kevin D. E. Stokesbury ${ }^{1}$, Bradley G. Stevens ${ }^{2}$, \\ Mark A. Altabet ${ }^{1}$ \\ ${ }^{1}$ University of Massachusetts Dartmouth School for Marine Science and Technology, New Bedford, Massachusetts 02744, \\ USA \\ ${ }^{2}$ University of Maryland Eastern Shore Living Marine Resources Cooperative Science Center, Princess Anne, \\ Maryland 21853, USA
}

\begin{abstract}
Shell disease (SD) has been observed in lobster populations for almost a hundred years, but recently, rates of an epizootic form of shell disease (ESD) have increased in the southern New England (USA) area. A large proportion of fish in the diet of American lobsters Homarus americanus has been linked to increased rates of SD. Therefore, the use of fish as lobster bait may be linked to increased ESD rates in lobsters. Lobsters from the western portion of Martha's Vineyard, MA $\left(41^{\circ} \mathrm{N}\right.$, $\left.71^{\circ} \mathrm{W}\right)$, were randomly divided into 3 groups of 16 and exposed to dietary treatments $(100 \%$ herring; $48 \%$ crab, $48 \%$ blue mussel and $4 \%$ plant matter; or $50 \%$ herring, $24 \%$ crab, $24 \%$ mussel, $2 \%$ plant matter) to determine if lobster tissue $\delta^{15} \mathrm{~N}$ levels reflected diet. The results of the feeding experiment confirmed that differences in diet are observed in the $\delta^{15} \mathrm{~N}$ levels of lobster muscle tissue. The $\delta^{15} \mathrm{~N}$ levels of tissue samples from 175 wild lobsters with varying degrees of ESD were unrelated to ESD severity but did indicate lobsters were eating large amounts of fish (bait). This result does not support the speculation that fish used as bait is contributing to ESD outbreaks in portions of the southern New England area.
\end{abstract}

KEY WORDS: Decapod crustacean $\cdot$ Feeding behaviour $\cdot$ Diet $\cdot \delta^{15} \mathrm{~N}$

\section{INTRODUCTION}

The American lobster Homarus americanus fishery is one of the most valuable in the Northwest Atlantic with annual landings in the US worth over \$372 million (ASMFC 2009). Stock abundance has increased in the 2 major lobster fishing grounds, Gulf of Maine and Georges Bank, but the Southern New England (SNE) stock has declined (ASMFC 2009). The cause of this decline is unclear; however, devastating disease outbreaks may be a contributing factor. In 1999, increased mortality most likely caused by microbial invasion coupled with other stressors reduced lobster landings in Long Island Sound by $90 \%$ (French et al. 2001). As exemplified in Long Island Sound, the study and understanding of these potentially threatening dis- eases is imperative, as disease outbreaks have the capability to generate substantial economic and biological losses. One such ailment, epizootic shell disease (ESD), has been present in the northern areas of SNE at low levels for decades (Glenn \& Pugh 2005) and has recently increased in range and occurrence (Smolowitz 2005).

Lobster shell disease (SD) results in the degradation of the lobster exoskeleton with lesions developing in heavily affected areas, exposing lobster tissue (Fig. 1). The most problematic form of shell disease in the SNE area, ESD, results from protein removal from the chitinoprotein matrix that comprises the lobster carapace, resulting in erosion of the cuticle and development of a pseudomembrane near the affected area (Smolowitz et al. 2005). This differs from classical shell 

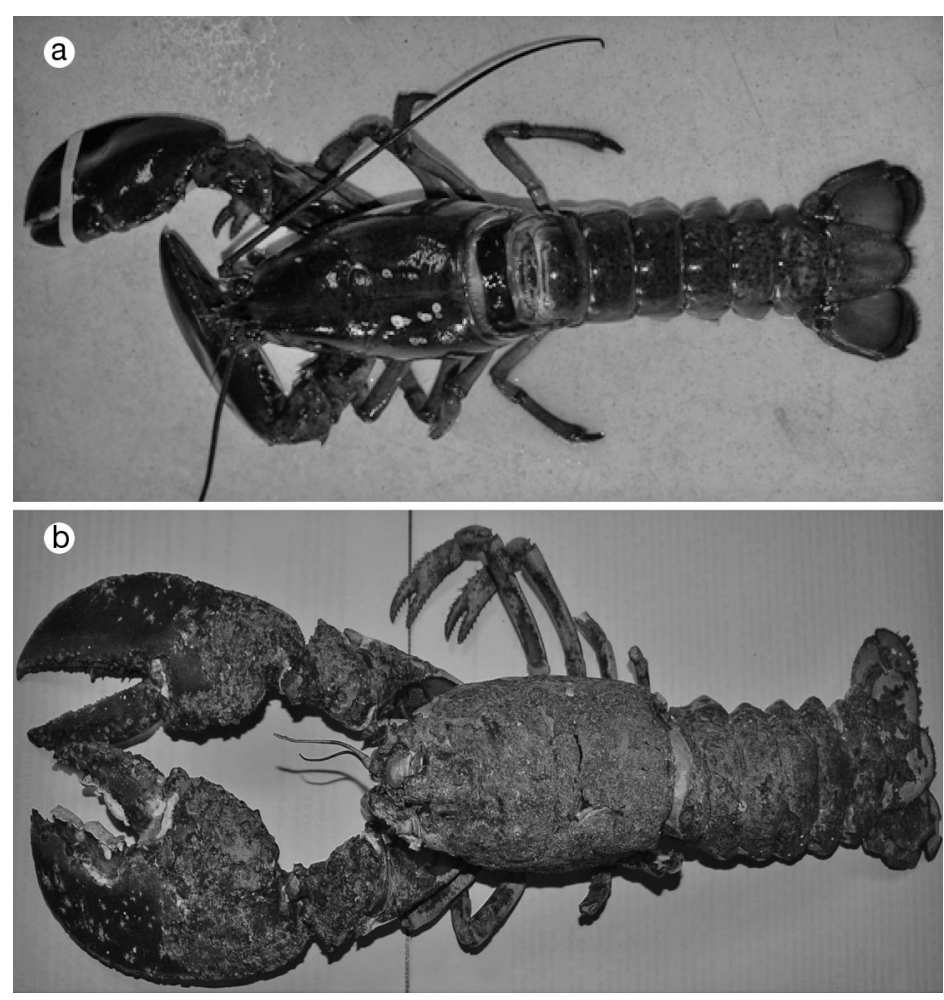

Fig. 1. Homarus americanus. American lobsters (a) without and (b) with severe epizootic shell disease

diseases (CSDs), in which invading bacteria consume the chitin of the chitinoprotein matrix, resulting in complete tissue exposure or deep pits in the shell (Getchell 1989). Although the specific pathology of ESD is unique (see Smolowitz et al. 2005 for further description), it is similar to CSDs in that it is a result of opportunistic, bacterial invasion through the cuticle (the outermost layer of the lobster shell), leading to the deterioration of the exoskeleton (Sindermann 1991, Tlusty et al. 2007). All forms of lobster SD are related to cuticle creation, repair, and loss, which are influenced by fitness (Sindermann 1991, see Tlusty et al. 2007 for detailed explanation). The effects of SD contribute to increased mortality by reducing external defenses against predation and tissue laceration, diminishing foraging ability, inhibiting a proper molt, and reducing growth per molt (Floreto et al. 2000a, Stevens 2009). Lobsters with notable or severe SD cannot be sold live; although the tissue is untainted, their unappetizing appearance results in a loss of profit for fishermen.

A diet comprised largely of fish has been linked to CSDs (Prince et al. 1995, Tlusty et al. 2008, Myers \& Tlusty 2009). Fish are a minor portion of lobster diet in unfished areas (Hudon \& Lamarche 1989, Lawton \& Lavalli 1995, Sainte-Marie \& Chabot 2002). However, large quantities of fish are used as lobster bait, and it is likely that bait is a consistent food source for lobsters in fished areas, as $>90 \%$ of lobsters that enter traps escape, and old or unusable bait is discarded overboard, allowing it to be scavenged by lobsters (Karnofsky \& Price 1989, Jury et al. 2001). Gut content and isotope analysis of lobsters caught by SCUBA divers in heavily fished areas has also shown fish to comprise a significant amount of lobster diet (Steneck 1987, Grabowski 2005, Grabowski et al. 2005, 2009, 2010). Although studies have shown that wild lobsters consume large amounts of bait, it is not their only food source, and the importance of bait to lobster diet can vary regionally (Grabowski et al. 2009). Mixing $50 \%$ non-fish foodstuffs into a lobster's diet significantly reduced SD rates (Tlusty et al. 2008).

Nitrogen isotope ratio analysis can be used to examine the diet of wild animals. In the atmosphere approximately $99.63 \%$ of nitrogen atoms are ${ }^{14} \mathrm{~N}$ while $0.37 \%$ are the heavier ${ }^{15} \mathrm{~N}$ (Robinson 2001). Biological processes can alter the ratio of these 2 isotopes with the quantity of ${ }^{15} \mathrm{~N}$ in the sample compared to its natural abundance expressed as $\delta^{15} \mathrm{~N} \%$. Predators have higher $\delta^{15} \mathrm{~N}$ signatures relative to their prey due to isotopic fractionation (Minagawa \& Wada 1984, Ehleringer et al. 1986, Vander Zanden \& Rasmussen 2001, Martinez del Rio et al. 2009, Le Vay \& Gamboa-Delgado 2011). Grabowski et al. $(2005,2010)$ successfully used nitrogen isotope analysis to determine the contribution of herring to lobster tissue in the mid-coast Gulf of Maine. However, because $\delta^{15} \mathrm{~N}$ of animal tissues can have regional and seasonal differences, a laboratory replication of Grabowski et al.'s (2005) findings for the study region is prudent (Sherwood \& Rose 2005).

This study examines the relationship between diet, $\delta^{15} \mathrm{~N}$, and ESD severity in American lobsters off western Martha's Vineyard, MA (WMV), by testing 3 null hypotheses: $H_{01}: \delta^{15} \mathrm{~N}$ values between diets with increasing amounts of fish are not significantly different; $H_{02}$ : $\delta^{15} \mathrm{~N}$ tissue values of lobsters consuming diets with different amounts of fish are not significantly different; and $H_{03}$ : $\delta^{15} \mathrm{~N}$ tissue values of wild lobsters with different ESD severities are not significantly different. The rejection of $H_{01}$ and $H_{02}$ will establish lobster tissue $\delta^{15} \mathrm{~N}$ values as reflecting relative fish consumption, allowing $H_{03}$ to test if ESD severity is related to diet. Unlike the laboratory studies that used restricted diets, the present study investigated the link between ESD severity and fish consumption in wild lobsters (Prince et al. 1995, Tlusty et al. 2008, Myers \& Tlusty 2009). 


\section{MATERIALS AND METHODS}

Experimental diets consisted of a wild diet (W), $100 \%$ herring $(\mathrm{H})$, and a mixed diet $(\mathrm{M})$. A diet of $48 \% \mathrm{crab}, 48 \%$ mussel, and $4 \%$ Spirulina algae is an acceptable experimental 'wild' diet (Tlusty et al. 2008, Myers \& Tlusty 2009) and is consistent with observations of wild lobster ecology and diet (MacKenzie \& Moring 1985, Elner \& Campbell 1987, Hudon 1987, Hudon \& Lamarche 1989, Lawton \& Lavalli 1995). Jonah crabs Cancer borealis were purchased from Point Judith, RI, fishermen, and blue mussels Mytilus edulis were collected from Buzzard Bay, MA. Both species were obtained during June 2009 to eliminate regional and seasonal differences that may occur in $\delta^{15} \mathrm{~N}$ levels (Wainright \& Fry 1994, Sherwood \& Rose 2005). The $M$ diet consisted of $50 \%$ herring, $24 \%$ crab, $24 \%$ mussel, and $2 \%$ plant matter. Herring Clupea harengus, commonly used as lobster bait, was purchased from Fairhaven Bait and Tackle. Many lobstermen in SNE use local fish carcasses (predominantly Atlantic cod Gadus morhua) as opposed to herring for lobster bait. Atlantic cod and other fish species also have significantly higher $\delta^{15} \mathrm{~N}$ levels than wild prey species and are similar to herring (Hobson \& Montevecchi 1991, Lawson \& Hobson 2000). Therefore, elevated $\delta^{15} \mathrm{~N}$ levels in lobsters from WMV likely indicate elevated amounts of fish in their diet.

Approximately $6 \mathrm{~kg}$ of each diet was required to feed the lobsters an adequate amount of food (a daily ration of $1 \%$ of their body weight) for the $129 \mathrm{~d}$ experiment (Castell \& Covey 1976). Each diet type was blended into a homogenized liquid then combined with gelatin in a 6:1 ratio for consistency. Once each diet had been created, 10 samples of each diet were dried for $48 \mathrm{~h}$ in a Fisher Scientific Isotemp oven at $40^{\circ} \mathrm{C}$, then homogenized using a mortar and pestle. About $1 \mathrm{mg}$ of each sample was placed in a tin weighing capsule. Ten samples of each diet were analyzed at 5 times (a total of 50 samples for each diet) during the experiment to ensure the $\delta^{15} \mathrm{~N}$ levels of the diets were stable. Initial diet samples were analyzed at the University of California Davis Stable Isotope Facility. All other isotopic analyses were conducted at the University of Massachusetts Dartmouth School for Marine Science and Technology (SMAST) isotope laboratory (under the supervision of Dr. M. Altabet). Samples analyzed at SMAST were combusted using a EURO Vector elemental analyzer and measured by a GV IsoPrime continuous flow isotope ratio mass spectrometer standardized against atmospheric nitrogen levels. Results were corrected to glycine or $\varepsilon$-amino-n-caproic-acid (Sigma) standards that were run before each sample batch and every 5th sample throughout analysis $\left(\delta^{15} \mathrm{~N}\right.$ precision $\pm 0.2 \%$ ). A real-time graph of each sample's analysis was also observed to ensure accuracy. An analysis of variance (ANOVA) was used to statistically compare samples, and Tukeys post hoc test was used to compare treatments when significant differences were detected.

Lobsters were collected from commercial traps on 16 June 2009 off WMV (approximately $41^{\circ} \mathrm{N}, 71^{\circ} \mathrm{W}$ ) (Fig. 2). In total, 48 lobsters were exposed to the dietary treatments for $129 \mathrm{~d}$ to evaluate the effects of $\mathrm{H}, \mathrm{W}$, and $\mathrm{M}$ diets on $\delta^{15} \mathrm{~N}$ signatures of lobster tissue. A sample size of 16 for each treatment was shown to be adequate trough analysis of data from Grabowski et al. (2005) for large lobsters (66 to $83 \mathrm{~mm}$ carapace length) captured around Monhegan and George's Islands, ME, in October, when bait was not an available food source for lobsters around Monhegan Island. The mean lobster $\delta^{15} \mathrm{~N}$ tissue values and standard deviations of their results were approximately $11.6 \pm 0.45$ and $10.2 \pm 0.89$, respectively. Following Krebs (1989), using the coefficient of variation $(\mathrm{CV})$ and relative error in percent $(r)$, determination of the sample size needed for adequate statistical strength was calculated as follows, based on a desired detection limit equal to $5 \%$ of the mean:

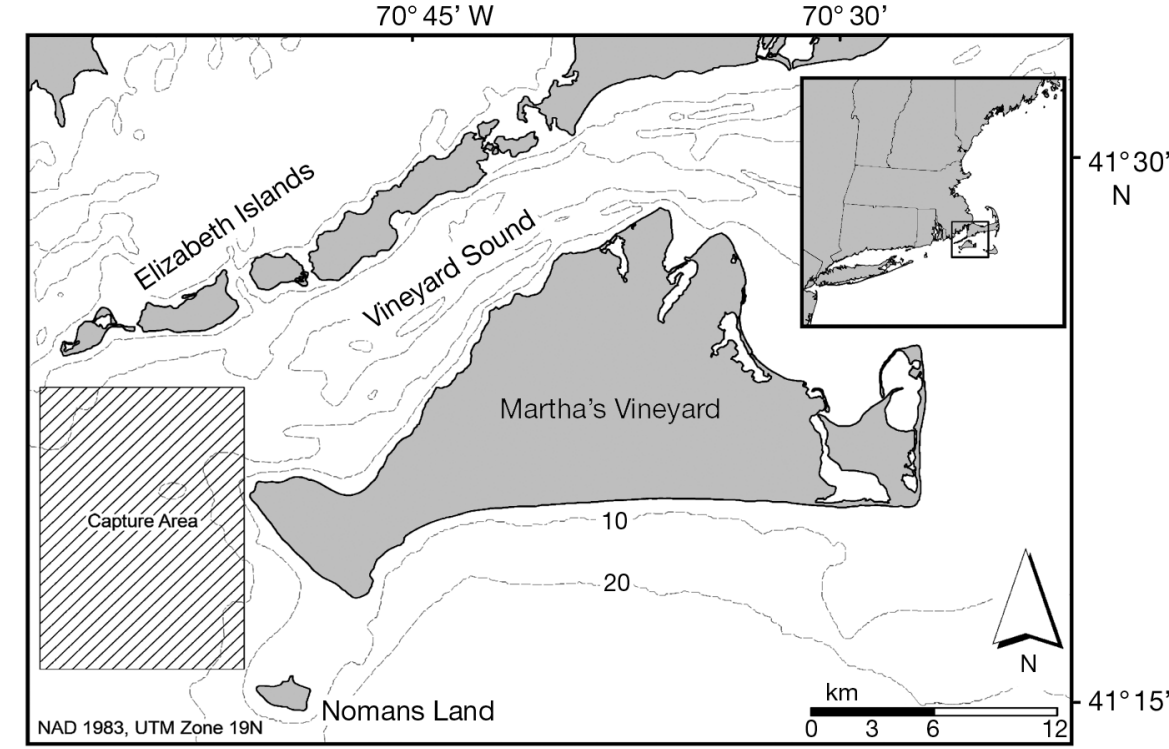

Fig. 2. Martha's Vineyard, MA, USA, surrounding waters and the area where lobsters used for the study were captured 


\author{
Sample size $=(200 \times \mathrm{CV} / \mathrm{r})^{2}$ \\ Monhegan Island results: Sample size $=$ \\ $(200 \times 0.09 / 5)^{2} \approx 13$ \\ Georges Island results: Sample size $=$ \\ $(200 \times 0.04 / 5)^{2} \approx 3$
}

Additionally, a power analysis of a 1-way ANOVA in SYSTAT 11 between the 2 reported means using the greater standard deviation from Grabowski et al. (2005) data (0.89) revealed a sample size of 8 necessary to achieve a statistical power $>0.8$.

Carapace lengths ( $\mathrm{mm}$ ) and weights $(\mathrm{g})$ of lobsters were recorded at the SMAST seawater laboratory on the day of capture. Lobsters selected for the experiment had less than $5 \%$ ESD coverage, 70 to $90 \mathrm{~mm}$ carapace length, no visible eggs, and no significant damage (missing >2 legs, open wounds, etc.) when caught. Lobsters were assigned a random number with the lowest 16 numbers fed $W$, middle 16 fed $M$, and highest 16 fed $\mathrm{H}$. Feeding did not begin until 20 June 2009 to allow the lobsters to acclimate. An ANOVA on initial carapace lengths and lobster weights detected no difference in lobster size between treatment groups.

Lobsters were placed into individual plastic bins with perforated sides in 2 stacked, recirculating tanks equipped with a water chiller set at $17^{\circ} \mathrm{C}$. Temperature was recorded every $2 \mathrm{~h}$ using a HOBO U22 Water Temp Pro v2 logger, and ammonia levels were measured weekly using a LaMotte salt water aquaculture test kit. Throughout the experimental period, temperature ranged from approximately 13 to $20^{\circ} \mathrm{C}$ with an average temperature of $16.0 \pm 1.56^{\circ} \mathrm{C}(\mathrm{N}=117)$, and ammonia levels in the recirculating system were $<0.6 \mathrm{ppm}$. Half of each treatment group was placed in either the top or bottom tank and arranged in a Latin square to account for discrepancies in flow, lighting, and temperature in different areas and levels of the tanks. Lobsters were fed approximately $2.5 \%$ of the mean experimental lobster weight 3 times a week for 129 d. Excess food and waste was siphoned from individual lobster bins $3 \mathrm{~h}$ after feeding.

Each measurement required approximately $1 \mathrm{mg}$ of dried lobster tissue, which was obtained by removing a single pleopod (a small appendage on the underside of the lobster abdomen) once every $2 \mathrm{wk}$ for the first 2 mo, then monthly until all 8 pleopods were removed. Tissue was separated from the shell before drying. Pleopod sample preparation and $\delta^{15} \mathrm{~N}$ analysis methods were conducted in the same manner as the diet analysis. $\delta^{15} \mathrm{~N}$ was measured before and after the experiment. If the initial and final $\delta^{15} \mathrm{~N}$ levels were significantly different, a middle sample was measured.

The time it would take the experimental lobster tissue $\delta^{15} \mathrm{~N}$ levels to reach isotopic equilibrium with the experimental diets ( 2 to $4 \%$ higher than the diet)
(Minagawa \& Wada 1984), known as $\delta^{15} \mathrm{~N}$ turnover rate, was calculated as in Kaufman et al. (2008):

$$
\delta_{t}=\delta_{\mathrm{f}}+\left(\delta_{0}-\delta_{\mathrm{f}}\right) \mathrm{e}^{-c t}
$$

where $\delta_{t}=\delta^{15} \mathrm{~N}$ at time $t, \delta_{\mathrm{f}}=$ expected $\delta^{15} \mathrm{~N}$ value at isotopic equilibrium (which was calculated by adding 3.4 to experimental diet means) (Minagawa \& Wada 1984), $\delta_{0}=$ initial $\delta^{15} \mathrm{~N}$ before the experiment, $c=$ turnover rate, and $t=$ time in days since diet switch. Once $c$ was determined, turnover half-life (the amount of time it would take the lobster tissue $\delta^{15} \mathrm{~N}$ value to reach a point equidistant from its original value and the equilibrium value of the new diet) was calculated as:

$$
\text { Half-life }=\ln (0.5) / C
$$

The relative contribution of growth $(g)$ and metabolic activity $(m)$ to turnover was determined by:

$$
c=g+m
$$

where $g=\ln \left(W_{\mathrm{f}} / W_{0}\right) / t, \quad W_{\mathrm{f}}=$ lobster weight at final tissue sample, and $W_{0}=$ initial lobster weight. Average variable values were used to calculate half-life and contribution of $m$ to turnover for each diet group. These values were averaged to obtain an overall half-life and metabolic contribution to turnover for the study.

The $\delta^{15} \mathrm{~N}$ values of the lobster tissues sampled before and after the experimental feeding regime were analyzed with two 1-way ANOVAs followed by Tukey's post hoc test. Paired $t$-tests were used to investigate if $\delta^{15} \mathrm{~N}$ values of lobsters in specific diet groups changed. If these results were significant, a repeated measures ANOVA and paired $t$-tests with Bonferroni corrections were used to test if $\delta^{15} \mathrm{~N}$ had changed significantly at the mid-point of the experiment. Molt and egg extrusion events were recorded and were tested with a 2-way ANOVA to see if these events significantly altered $\delta^{15} \mathrm{~N}$ values.

Pleopods of lobsters were removed at sea and placed in labeled vials after length, sex, and ESD severity of the sampled lobster were recorded. Tissue was obtained from wild lobsters with the same physical characteristics as the laboratory lobsters (with the exception of ESD state). The ESD status in wild lobsters was evaluated using a standardized overall visual assessment of ESD in 4 levels: $0=$ none present, $1=$ $<10 \%$ coverage, $2=10$ to $50 \%$ coverage, and $3=$ $>50 \%$ coverage (Landers 2005). Tissues from wild lobsters were processed and analyzed for $\delta^{15} \mathrm{~N}$ in the same manner as described for diet samples. Values of $\delta^{15} \mathrm{~N}$ for the wild lobster samples were compared between ESD categories using a 1-way ANOVA and Tukey's post hoc test if necessary. Additionally, a Spearman rank correlation analysis was conducted to determine if a positive relationship existed between ESD and $\delta^{15} \mathrm{~N}$ levels of wild WMV lobsters. 


\section{RESULTS}

Diets with higher amounts of fish had significantly higher $\delta^{15} \mathrm{~N}$ values throughout the study (ANOVA with Tukey's post hoc test, $F_{2,149}=6.716$, all p-values $<0.001$ ) (Fig. 3).

During the study, 9 lobsters molted, 13 extruded eggs, 2 died, and 24 lobsters did not undergo physiological changes. The 2 lobsters that died and 1 additional lobster whose initial tissue sample was lost during $\delta^{15} \mathrm{~N}$ analysis were excluded from all statistical tests. This resulted in 3 groups of 15 lobsters rather than 3 groups of 16 lobsters.

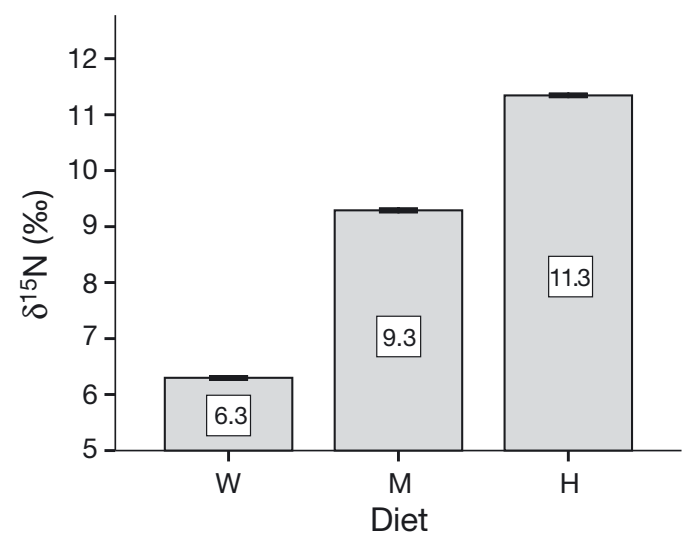

Fig. 3. Mean $\delta^{15} \mathrm{~N}$ values $( \pm 1 \mathrm{SE}$ ) of experimental diets consisting of $100 \%$ wild food stuffs (W), $50 \%$ herring and $50 \%$ wild food stuffs (M), or $100 \%$ herring $(\mathrm{H})$

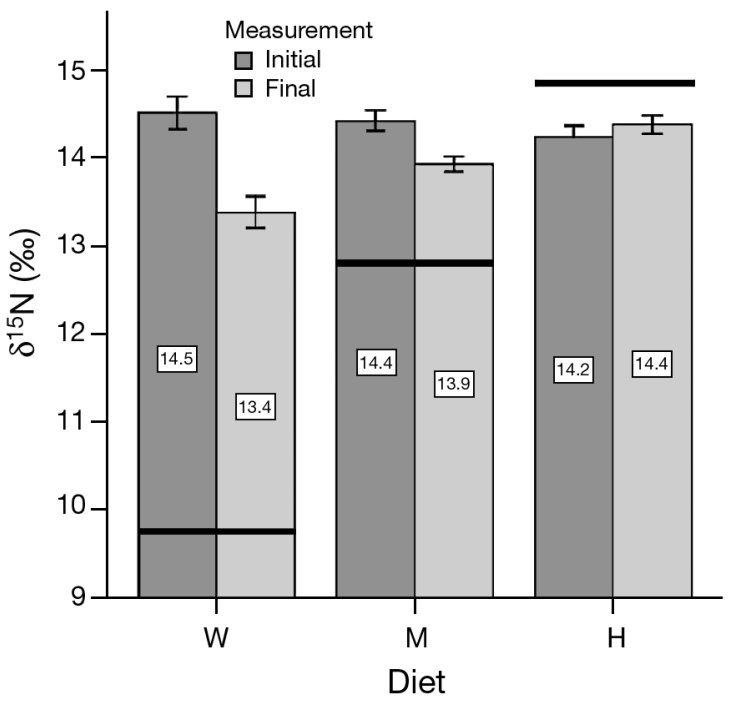

Fig. 4. Homarus americanus. Mean $( \pm 1 \mathrm{SE}) \delta^{15} \mathrm{~N}$ tissue values of lobsters fed experimental diets consisting of $100 \%$ wild food stuffs (W), $50 \%$ herring and $50 \%$ wild food stuffs (M), or $100 \%$ herring $(\mathrm{H})$ taken before and after the $129 \mathrm{~d}$ experimental period. Black horizontal lines represent the expected

$\delta^{15} \mathrm{~N}$ tissue values at isotopic equilibrium with each diet
There was no difference between any of the diet treatment groups in initial weight (ANOVA, $F_{2,45}=$ 0.38, p = 0.68) (data not shown), length (ANOVA, $F_{2,45}=0.38, \mathrm{p}=0.69$ ) (data not shown), or mean $\delta^{15} \mathrm{~N}$ values (ANOVA, $F_{2,42}=0.90, \mathrm{p}=0.42$ ) (Fig. 4 ). At the end of the experiment, the mean $\delta^{15} \mathrm{~N}$ values were significantly different between all groups (ANOVA with Tukey's post hoc test, $F_{2,42}=15.04$, all p-values $<0.05$ ) (Fig. 4). Molting or extruding eggs had no effect on $\delta^{15} \mathrm{~N}$ values (2-way ANOVA, $\left.F_{2,36}=1.62, \mathrm{p}=0.21\right)$. The final $\delta^{15} \mathrm{~N}$ values of the lobsters fed $\mathrm{W}$ and $\mathrm{M}$ were significantly lower than their initial values (paired $t$-tests, $t_{14}=-7.77, \mathrm{p}<0.001$ for $\mathrm{W}_{;} t_{14}=-3.48, \mathrm{p}<0.005$ for $\mathrm{M}$ ) (Fig. 4). The final $\delta^{15} \mathrm{~N}$ values of lobster fed Diet $\mathrm{H}$ were not significantly different from their initial values (paired $t$-test, $t_{14}=0.96, \mathrm{p}=0.35$ ) (Fig. 4). Only lobsters fed Diet W had significantly different mean $\delta^{15} \mathrm{~N}$ values at the beginning, middle, and end of the experiment (repeated measures ANOVA, $F_{2,28}=36.78$, paired $t$-tests with Bonferroni correction, all p-values $<0.01)$. The mean half-life $( \pm \mathrm{SD})$ of isotopic turnover was $301 \pm 33 d(\mathrm{~N}=2)$ and the mean percent metabolic contribution to isotopic turnover was $94 \pm 5 \%(\mathrm{~N}=2)$. Values of $\delta^{15} \mathrm{~N}$ from the $\mathrm{H}$ treatment were not included in these calculations because no significant change was detected.

Of the 175 lobsters whose pleopods were analyzed, 73 had ESD rating 0, 32 ESD rating 1, 37 ESD rating 2, and 33 had ESD rating 3. Each ESD group contained lobsters of the same size with an overall average carapace length for all groups of $83 \mathrm{~mm}$ and a range of 72 to $90 \mathrm{~mm}$ (ANOVA, $F_{3,171}=2.38, \mathrm{p}=0.07$ ). All groups were predominantly female with no group having more than 3 males. No significant correlation was found between ESD severity and the $\delta^{15} \mathrm{~N}$ values of lobster tissues (Spearman rank correlation, $r_{\mathrm{s}}=0.14$, $\mathrm{N}=175, \mathrm{p}=0.06$ ). Additionally, no significant difference in the mean $\delta^{15} \mathrm{~N}$ values was found between lobsters in different ESD severity groups (ANOVA, $F_{3,171}=$ $0.83, \mathrm{p}=0.48$ ) (Fig. 5). The mean $\delta^{15} \mathrm{~N}$ value for all lobsters sampled was $14.5 \pm 0.04 \%$ 。 $(\mathrm{N}=175)$.

\section{DISCUSSION}

The low $\delta^{15} \mathrm{~N}$ signature of Diet W (mostly shellfish) compared to Diet $\mathrm{H}$ (fish) supports the notion that higher $\delta^{15} \mathrm{~N}$ levels in the tissue of WMV lobsters is the result of increased fish consumption. Unlike the lobsters fed Diets $\mathrm{M}$ and $\mathrm{W}$, lobsters fed Diet $\mathrm{H}$ did not have a significantly different mean $\delta^{15} \mathrm{~N}$ level after the feeding experiment. This lack of change is explained by the $\delta^{15} \mathrm{~N}$ signature of $\mathrm{H}$ (Fig. 4). The expected stepwise enrichment of the diet would yield a tissue $\delta^{15} \mathrm{~N}$ signature of about $14.7 \pm 1.1 \%$, which is similar to the 


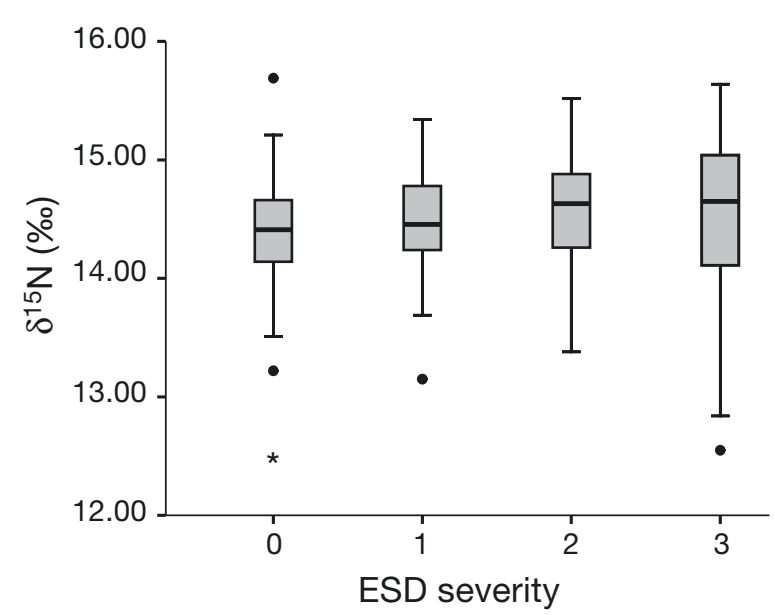

Fig. 5. Homarus americanus. $\delta^{15} \mathrm{~N}$ tissue values of lobsters with varying degrees of epizootic shell disease (ESD) caught off western Martha's Vineyard, MA, USA. The ESD severity of the lobsters was evaluated using an overall visual assessment of ESD in 4 levels: 0: no ESD present; 1: $<10 \%$ total ESD coverage; $2: 10$ to $50 \%$ ESD coverage; $3:>50 \%$ disease coverage. Points and stars represent data points that are outliers; horizontal lines are medians

initial lobster tissue $\delta^{15} \mathrm{~N}$ value (Minagawa \& Wada 1984). This result should not be extrapolated to conclude that wild lobsters only consume fish. As previously mentioned, local fishermen use a wide variety of fish bait with differing $\delta^{15} \mathrm{~N}$ levels. For example, the lowest reported mean $\delta^{15} \mathrm{~N}$ value for Atlantic cod, a popular bait fish of the area, is $13.9 \pm 0.57 \%$ o (Lawson $\&$ Hobson 2000). Consumption of fish with $\delta^{15} \mathrm{~N}$ values similar to Atlantic cod and subsequent $\delta^{15} \mathrm{~N}$ enrichment could elevate lobster tissue $\delta^{15} \mathrm{~N}$ levels to the initial values displayed without comprising $100 \%$ of a lobster diet.

Though the exact amount of fish consumed by WMV lobsters cannot be determined, the $\delta^{15} \mathrm{~N}$ level of Diet $\mathrm{W}$ and initial $\delta^{15} \mathrm{~N}$ signatures of the experimental lobsters suggest they are consuming a significant amount of fish. Although the $\delta^{15} \mathrm{~N}$ values of all the potential wild prey species were not analyzed, crabs and mussels are the most common prey items of wild lobsters (MacKenzie \& Moring 1985, Elner \& Campbell 1987, Hudon 1987, Hudon \& Lamarche 1989, Lawton \& Lavalli 1995). The low $\delta^{15} \mathrm{~N}$ signature of $\mathrm{W}$ (comprised almost entirely of crabs and mussels) makes it highly unlikely for a lobster consuming a similar diet to enrich its $\delta^{15} \mathrm{~N}$ signature to the initial levels observed in WMV lobsters (Minagawa \& Wada 1984, Le Vay \& Gamboa-Delgado 2011). The $\delta^{15} \mathrm{~N}$ signature of lobsters that consumed a non-fish diet had the most dramatic decrease. Therefore, the initial $\delta^{15} \mathrm{~N}$ signature of the lobsters is best explained by the consumption of fish.

Isotopic turnover rates from this study confirm that $\delta^{15} \mathrm{~N}$ levels of wild lobster tissue are a long-term aver- age of a lobster's diet rather than a reflection of the last meal. The calculated $\delta^{15} \mathrm{~N}$ half-life was considerably longer than in the red rock lobster Jasus edwardsii (147 d) (Suring \& Wing 2009), but numerous differences between the studies, such as species, tissue type sampled, length of experiment, size of animals, and composition of diets, could account for this disparity. Regardless of these differences, both studies suggest a relatively long $\delta^{15} \mathrm{~N}$ turnover rate for lobsters.

Lobster $\delta^{15} \mathrm{~N}$ levels were similar despite varying degrees of shell disease, suggesting diet and ESD in lobsters around WMV is unrelated. These results imply either that no relationship between exclusive fish consumption and ESD susceptibility exists or that lobsters are consuming a heterogeneous diet of sufficient quality to maintain health. The latter explanation is most likely, as Prince et al. (1995) and Tlusty et al. (2008) showed direct associations between fish consumption and increased CSDs, while the findings of Stewart et al. (1967), Sindermann (1991), Floreto et al. (2000a), Tlusty et al. (2007), Theriault et al. (2008), Myers \& Tlusty (2009) and Comeau \& Benhalima (2009) all link physiological consequences of $100 \%$ fish diets to potential mechanisms for or indicators of increased ESD susceptibility. In addition, studies quantifying the diet of wild lobsters in commercially exploited areas found no lobster diets comprised of $>80 \%$ fish (Steneck 1987 , Grabowski et al. 2005, 2009, 2010, Hanson 2009).

It is possible that narrow diet composition rather than specifically fish was the cause of nutritional deficiency in previous experiments. Lobsters fed fish have increased growth rates (Donahue et al. 1998, Grabowski et al. 2005, 2010, Tlusty et al. 2008) and lower Ca:P ratios than lobsters fed a 'wild' diet (Myers \& Tlusty 2009). Elevated Ca:P ratios lead to shell abnormalities and decreased survival in lobsters (Gallagher et al. 1978). Thus, the incorporation of fish in a lobster diet may be beneficial. A diet of only urchin and blue mussel did not allow lobsters to maintain growth and energy reserves, implying nutritional deficiency (Gendron et al. 2001). A varied diet rather than 'not fish' may be more important to lobster fitness. Varied diets have achieved better success at lobster rearing, and no single food organism has been identified as optimal for captive lobsters (Boghen \& Castell 1981, Floreto et al. 2000b, Tlusty et al. 2005). Analysis of wild lobster feeding habits have revealed dominant prey items, but in general, lobsters feed on a wide variety of prey rather than an exclusive single-prey or even single-genus diet (Elner \& Campbell 1987, Hudon \& Lamarche 1989, Sainte-Marie \& Chabot 2002, Grabowski et al. 2005, 2009, 2010, Hanson 2009). These studies emphasize the point that lobsters are generalists, and a narrow diet composition will likely have negative effects regardless of the ingredients. 
The disconnect between areas where fish is used as bait (throughout the fishery) and widespread SD in wild lobsters (in SNE) does not diminish the value of this research. Our study did not seek to test if ESD was caused by diet but to see if there was a correlation. The most important factor in determining if a lobster succumbs to SD is its internal state or fitness (Sindermann 1991, Tlusty et al. 2007) and lobsters exposed to multiple stressors are more susceptible to disease (Robohm et al. 2005). Therefore, lobsters persisting on a nutritionally deficient diet may be able to prevent microbial invasion as long as additional stresses are not present. The SNE area can be considered part of the southern extent of significant lobster populations and therefore represents a high-stress habitat (Whittaker 1975). Specifically, lobsters of SNE are exposed to higher temperatures and pollution levels than lobsters of the northern stocks (ASMFC 2009). Excessive consumption of fish and the associated nutritional deficiencies could reduce the fitness of a lobster and its ability to overcome multiple stressors, making it more susceptible to SD in high-stress areas.

Acknowledgements. Thank you to Dr. M. Tlusty for his support and review of the research, as well as for the opportunity to work with him. We thank the captain of the FV 'Sherry and Dyke', A. DeCosta, for his general knowledge and assistance in acquiring lobsters. This research was funded through the National Oceanic and Atmospheric Administration grants NA07NMF4720359, NA08NMF4720553, and NA09NMF4720257. The views expressed in this paper are the authors' and do not necessarily reflect the views of NOAA or any other agencies.

\section{LITERATURE CITED}

ASMFC (Atlantic States Marine Fisheries Commission) (2009) American lobster stock assessment report for peer review. Stock Assessment report no. 09-01 (supplement). ASMFC, New York, NY

> Boghen AD, Castell JD (1981) Nutritional value of different dietary proteins to juvenile lobsters, Homarus americanus. Aquaculture 22:343-351

Castell JD, Covey JF (1976) Dietary lipid requirements of adult lobsters, Homarus americanus (M.E.). J Nutr 106: 1159-1165

Comeau M, Benhalima K (2009) Internal organ pathology of wild American lobster (Homarus americanus) from eastern Canada affected with shell disease. NZ J Mar Freshw Res 43:257-269

Donahue DW, Bayer RC, Riley JG (1998) Effects of diet on weight gain and shell hardness of new-shell American lobster, Homarus americanus. J Appl Aquacult 8:79-85

Ehleringer JR, Rundel PW, Nagy KA (1986) Stable isotopes in physiological ecology and food web research. Trends Ecol Evol 1:42-45

- Elner RW, Campbell A (1987) Natural diets of lobster Homarus americanus from barren ground and macroalgal habitats off southwestern Nova Scotia, Canada. Mar Ecol Prog Ser 37:131-140
Floreto EAT, Prince DL, Brown PB, Bayer RC (2000a) The biochemical profiles of shell-diseased American lobsters, Homarus Americanus Milne Edwards. Aquaculture 188: $247-262$

Floreto EAT, Bayer RC, Brown PB (2000b) The effects of soybean-based diets, with and without amino acid supplementation, on growth and biochemical composition of juvenile American lobster, Homarus americanus. Aquaculture 189:211-235

French RA, Tucker M, DeGuise S, Frasca S and others (2001) Assessment of lobster health in Long Island Sound 2000-2001. Long Island Sound lobster health symposium, Ronkonkoma, NY, November 29-30, 2001. New York Sea Grant, Stony Brook, NY, p 4

Gallagher ML, Brown WD, Conklin DE, Sifri M (1978) Effects of varying calcium/phosphorus ratios in diets fed to juvenile lobsters (Homarus americanus). Comp Biochem Physiol 60:467-471

Gendron L, Fradette P, Godbout G (2001) The importance of rock crab (Cancer irroratus) for growth, condition and ovary development of adult American lobster (Homarus americanus). J Exp Mar Biol Ecol 262:221-241

Getchell RG (1989) Bacterial shell disease in crustaceans: a review. J Shellfish Res 8:1-6

Glenn RP, Pugh TL (2005) Observations on the chronology and distribution of lobster shell disease in Massachusetts coastal waters. New England Aquarium, Boston, MA. Report no. 05-1

Grabowski J (2005) Interactions among lobster diet, the environment, and lobster health: linking dietary changes and environmental pollutants to the incidence of shell disease. Boston, MA: New England Aquarium. Report no. 05-1

Grabowski J, Clesceri E, Yund P, Weber M, Poland P, Myrick $M$ (2005) Are we using herring to farm lobsters? The effect of herring bait on lobster growth, and the fate of discarded bait on bottom habitat. Gulf of Maine Research Institute, Portland, ME. Report no. 02-566

> Grabowski J, Clesceri E, Yund P (2009) The role of food limitation in lobster population dynamics in coastal Maine, United States, and New Brunswick, Canada. NZ J Mar Freshw Res 43:185-193

Grabowski JH, Clesceri EJ, Baukus AJ, Gaudette J, Weber M, Yund PO (2010) Use of herring bait to farm lobsters in the Gulf of Maine. PLoS ONE 5:e10188

> Hanson JM (2009) Predator-prey interactions of American lobster (Homarus americanus) in the southern Gulf of St. Lawrence, Canada. NZ J Mar Freshw Res 43:69-88

Hobson KA, Montevecchi WA (1991) Stable isotopic determination of trophic relationships of great auks. Oecologia $87: 528-531$

Hudon C (1987) Ecology and growth of postlarval and juvenile lobster, Homarus americanus, off Iles de la Madeleine (Quebec). Can J Fish Aquat Sci 44:1855-1869

Hudon C, Lamarche G (1989) Niche segregation between American lobster Homarus americanus and rock crab Cancer irroratus. Mar Ecol Prog Ser 52:155-168

> Jury SH, Howell H, O'Grady DO, Watson WH (2001) Lobster trap video: in situ video surveillance of the behavior of Homarus americanus in and around traps. Mar Freshw Res 52:1125-1132

> Karnofsky EB, Price HJ (1989) Behavioral response of the lobster, Homarus americanus, to traps. Can J Fish Aquat Sci 46:1625-1632

Kaufman MR, Gradinger RR, Bluhm BA, O'Brien DM (2008) Using stable isotopes to assess carbon and nitrogen turnover in the Arctic sympagic amphipod Onisimus litoralis. Oecologia 158:11-22 
Krebs CJ (1989) Ecological methodology. Harper \& Row, New York, NY

Landers DF (2005) Prevalence and severity of the shell disease in American lobster (Homarus americanus) from eastern Long Island Soound, Connecticut. Report no. 095-1. New England Aquarium, Boston, MA

Lawson JW, Hobson KA (2000) Diet of harp seals (Pagophilus groenlandicus) in nearshore northeast Newfoundland: inferences from stable-carbon $\left(\delta^{13} \mathrm{C}\right)$ and nitrogen $\left(\delta^{15} \mathrm{~N}\right)$ isotope analyses. Mar Mamm Sci 16:578-591

Lawton P, Lavalli K (1995) Postlarval, juvenile, adolescent, and adult ecology. In: Factor JR (ed) Biology of the lobster Homarus americanus. Academic Press, San Diego, CA, p 47-102

Le Vay L, Gamboa-Delgado J (2011) Naturally-occurring stable isotopes as direct measures of larval feeding efficiency, nutrient incorporation and turnover. Aquaculture 315:95-103

MacKenzie C, Moring JR (1985) Species profiles: life histories and environmental requirements of coastal fishes and invertebrates (North Atlantic)-American lobster. Biol Rep US Fish Wildl Serv 82(11.33), US Army Corps of Engineers (report no. TR EL-82-4), Vicksburg, MS

Martinez del Rio C, Wolf N, Carleton SA, Gannes LZ (2009) Isotopic ecology ten years after a call for more laboratory experiments. Biol Rev Camb Philos Soc 84:91-111

Minagawa M, Wada E (1984) Stepwise enrichment of ${ }^{15} \mathrm{~N}$ along food chains: further evidence and the relation between $\delta^{15} \mathrm{~N}$ and animal age. Geochim Cosmochim Acta 48:1135-1140

Myers A, Tlusty MF (2009) A long-term assessment of the physiological effects of herring (Clupea harengus) as a dietary component of the American lobster (Homarus americanus). NZ J Mar Freshw Res 43:173-183

Prince DL, Bayer RC, Galagher ML, Subramanyam M (1995) Reduction of shell disease with an experimental diet in a Nova Scotia lobster pound. J Shellfish Res 14:205-207

Robinson D (2001) $\delta^{15} \mathrm{~N}$ as an integrator of the nitrogen cycle. Trends Ecol Evol 16:153-162

Robohm RA, Draxler AJ, Wieczorek D, Kapareiko D, Pitchford S (2005) Effects of environmental stressors on disease susceptibility in American lobsters: a controlled laboratory study. J Shellfish Res 24:773-779

Sainte-Marie B, Chabot D (2002) Ontongenetic shifts in natural diet during benthic stages of American lobster (Homarus americanus) off the Magdalene Islands. Fish Bull 100:106-116

Sherwood GD, Rose GA (2005) Stable isotope analysis of some representative fish and invertebrates of the New- foundland and Labrador continental shelf food web. Estuar Coast Shelf Sci 63:537-549

Sindermann C (1991) Shell disease in marine crustaceans - a conceptual approach. J Shellfish Res 10:491-494

Smolowitz R (2005) Epizootic shell disease in the American lobster, Homarus americanus. Report no. 05-1. New England Aquarium, Boston, MA

Smolowitz R, Christoserdov A, Hsu A (2005) A description of the pathology of epizootic shell disease in the American lobster, Homarus americanus, H. Milne Edwards 1873. J Shellfish Res 24:749-756

Steneck RS (1987) Lobstermen pull traps for research. Gulf of Maine Foundation Newsletter. Making Waves 2:1-2

> Stevens BG (2009) Effects of epizootic shell disease in American lobster Homarus americanus determined using a quantitative disease index. Dis Aquat Org 88:25-34

Stewart JE, Cornick JW, Folex DM, Li MF, Bishop CM (1967) Muscle weight relationship to serum proteins, hemocytes, and hepatopancreas in the lobster, Homarus americanus. J Fish Res Board Can 24:2339-2354

Suring E, Wing SR (2009) Isotopic turnover rate and fractionation in multiple tissues of red rock lobster (Jasus edwardsii) and blue cod (Parapercis colias): consequences for ecological studies. J Exp Mar Biol Ecol 370:56-63

- Theriault M, Vanleeuwen J, Morrison M, Cawthorn R (2008) Risk factors for the development of shell disease in impounded populations of the American lobster, Homarus americanus. J Shellfish Res 27:1239-1245

- Tlusty MF, Fiore DR, Goldstein JS (2005) Use of formulated diets as replacements for Artemia in the rearing of juvenile American lobsters (Homarus americanus). Aquaculture 250:781-795

Tlusty MF, Smolowitz RM, Halvorson HO, DeVito SE (2007) Host susceptibility hypothesis for shell disease in American lobsters. J Aquat Anim Health 19:215-225

> Tlusty MF, Myers A, Metzler A (2008) Short- and long-term dietary effects on disease and mortality in American lobster Homarus americanus. Dis Aquat Org 78:249-253

Vander-Zanden MJ, Rasmussen JB (2001) Variation in $\delta^{15} \mathrm{~N}$ and $\delta^{13} \mathrm{C}$ trophic fractionation: implications for aquatic food web studies. Limnol Oceanogr 46:2061-2066

Wainright SC, Fry B (1994) Seasonal variation of the stable isotopic compositions of coastal marine plankton from Woods Hole, Massachusetts and Georges Bank. Estuaries 17:552-560

Whittaker RH (ed) (1975) Communities and environments. In: Communities and ecosystems, 2nd edn. MacMillian Publishing, New York, NY, p 111-185

Submitted: September 10, 2010; Accepted: February 24, 2011 Proofs received from author(s): May 16, 2011
Editorial responsibility: Grant Stentiford, Weymouth, UK 